\title{
Hydrocarbon charge history of the Paleogene reservoir in the northern Dongpu Depression, Bohai Bay Basin, China
}

\author{
You-Lu Jiang ${ }^{1} \cdot$ Lei Fang ${ }^{2} \cdot$ Jing-Dong Liu ${ }^{1} \cdot$ Hong-Jin $\mathrm{Hu}^{1} \cdot$ Tian-Wu $\mathrm{Xu}^{3}$
}

Received: 2 November 2015/Published online: 8 November 2016

(c) The Author(s) 2016. This article is published with open access at Springerlink.com

\begin{abstract}
The hydrocarbon charge history of the Paleogene in the northern Dongpu Depression was analyzed in detail based on a comprehensive analysis of the generation and expulsion history of the major hydrocarbon source rocks, fluorescence microscopic features and fluid inclusion petrography. There were two main stages of hydrocarbon generation and expulsion of oil from the major hydrocarbon source rocks. The first stage was the main hydrocarbon expulsion stage. The fluorescence microscopic features also indicated two stages of hydrocarbon accumulation. Carbonaceous bitumen, asphaltene bitumen and colloidal bitumen reflected an early hydrocarbon charge, whereas the oil bitumen reflected a second hydrocarbon charge. Hydrocarbon inclusions also indicate two distinct charges according to the diagenetic evolution sequence, inclusion petrography features combined with the homogenization temperature and reservoir burial history analysis. According to these comprehensive analysis results, the hydrocarbon charge history of the Paleogene reservoir in the northern Dongpu Depression was divided into two phases. The first phase was from the late Dongying depositional period of the Oligocene to the early uplift stages of the late Paleogene. The second phase was from the late Minghuazhen period of the Pliocene to the
\end{abstract}

You-Lu Jiang

jiangyl@upc.edu.cn

1 School of Geosciences, China University of Petroleum, Qingdao 266580, Shandong, China

2 CNOOC Research Institute, Beijing 100028, China

3 SINOPEC Zhongyuan Oil Company, Puyang 457001, Henan, China

Edited by Jie Hao
Quaternary. Reservoirs formed during the first period were widely distributed covering the entire area. In contrast, reservoirs formed during the second period were mainly distributed near the hydrocarbon generation sags. Vertically, it was characterized by a single phase in the upper layers and two phases in the lower layers of the Paleogene.

Keywords Dongpu Depression · Hydrocarbon charge history - Hydrocarbon generation and expulsion history . Fluid inclusion · Petrography · Fluorescence microscopy

\section{Introduction}

Hydrocarbon charge history is an important issue in the study of pool-forming. Determination of the hydrocarbon charge history is helpful to correctly understand the oil and gas reservoir formation and distribution and has important practical value for guiding petroleum exploration. Traditional hydrocarbon charge history analytical methods include the hydrocarbon generation and expulsion history analytical method, the trap development history method and the reservoir saturation pressure method. Since 1990s, many new methods such as fluid inclusion studies, reservoir bitumen analysis and diagenetic mineral dating have been widely used. In recent years, the fluid inclusion method has been widely used and has achieved good results (Zhao et al. 2013; Guo et al. 2012; Yang et al. 2014; Xiao et al. 2012, 2016; Jiang et al. 2015a, b, c; Liu et al. 2007a, b, 2013; Gui et al. 2015; Wu et al. 2013; Wang et al. 2015a, b). Fluid inclusions can provide valuable information on the reservoir pressure and temperature at the time of the fluid migration and entrapment as well as on the compositions of the fluids involved in diagenesis and may thus provide important insight into the mineral diagenesis and fluid dynamics within 
sedimentary basins (Dolníček et al. 2012; Shan et al. 2015; Wang et al. 2015a, b; Guo et al. 2014; Lü et al. 2015; Li 2016). Fluid inclusion entrapment temperature in conjunction with burial and thermal history plots can be used to determine the petroleum charge history (Parnell 2010; Liu et al. 2011; Pang et al. 2015). The key of fluid inclusion study — one of the most important methods-is the accurate division of hydrocarbon fluid inclusion formation stages. In hydrocarbon-rich depressions with multiple sets of hydrocarbon source rocks, oil and gas that generated in the same period but different structural positions could have different temperatures, different maturity and different fluorescent colors. Therefore, the fluorescent color and homogenization temperature cannot be used as the absolutely effective basis for dividing the phases of hydrocarbon inclusions (Tao 2006). Due to the irreversibility of diagenesis, and the simultaneity of the inclusions and their host minerals formation, it is more reliable to determine the hydrocarbon charge history according to the order of formation of the host minerals (Liu et al. 2007a, b; Tao 2006). But reservoirs of the same period but at different depths may be in different diagenetic evolution stages. So, fluid inclusions of different host minerals may be formed in the same period. Therefore, the fluid inclusion forming periods cannot be simply divided according to the sequence of host minerals in the diagenetic evolution stage. Because of the complexity of the formation and evolution of oil and gas reservoirs, a single method is often limited in the hydrocarbon charge history analysis, and it should be combined with a variety of methods, to ensure the reliability of the results. In this study, we integrated a variety of research methods to determine the hydrocarbon charge history of the Paleogene reservoir in the north of the Dongpu Depression. The hydrocarbon charge stages were divided qualitatively based on the analysis of generation and expulsion stages of major hydrocarbon source rocks and fluorescence microscopic features (Jarmołowicz-Szulc et al. 2012); the hydrocarbon fluid inclusion forming periods were divided according to the diagenetic evolution sequence of host minerals combined with reservoir burial evolution history. Then, the hydrocarbon charge time was determined according to the inclusions' homogenization temperature in conjunction with burial and thermal history plots.

\section{Geological setting}

The Dongpu Depression is located to the southwest of the Bohai Bay Basin with an area of about $5300 \mathrm{~km}^{2}$. Faults are developed in the depression (Chen et al. 2007; Jiang et al. 2015a), and controlled by this, a tectonic framework of "two sags, one uplift and one slope" was formed (Fig. 1). The depression underwent the rift stage in the Paleogene and the depression stage in the Neogene and the
Quaternary. From the Kongdian period to the Es 4 period which was the early rifting stage, the former cratonic basin disintegrated and formed a half-graben basin prototype. During the $\mathrm{Es}_{3}$ period, namely the strong rifting stage, the fault activity was strong, and the basic tectonic framework was established. The advanced fault depression stage was from the $\mathrm{Es}_{2}$ period to the Dongying period, during which the fault activity weakened, and uplift occurred in the late Dongying period, and there was great erosion $(\mathrm{Lu}$ et al. 2007). During the Neogene and Quaternary which was the depression stage, the tectonic activity was weak and most of the faults stopped being active (Jiang et al. 2015b). There is a series of hydrocarbon generation subdepressions in the depression, two of which are in the study area, the Liutun-Haitongii sub-depression and the PuchengQianliyuan sub-depression. Source rocks in the depression include the coal measures of the Carboniferous-Permian and the mud shale of the third and first member of the Shahejie Formation. The main hydrocarbon source rocks are the shale of the middle-lower sections of the third member of the Shahejie Formation. The reservoir strata are the sand layers of the Shahejie Formation. The several sets of mudstones and gypsum in the Shahejie Formation form high-quality caprocks. They were superposed and formed many sets of source rock-reservoir-caprock assemblage. More than $80 \%$ of the oil and gas reserves found in the depression are distributed in the north area (Fig. 1). Thus, the reservoir formation process of the northern part is also largely representative of the whole depression.

\section{Methodologies and samples}

\subsection{Hydrocarbon generation and expulsion history modeling}

The hydrocarbon generation and expulsion history of the source rocks in the Dongpu Depression were simulated using the basin modeling method (Makeen et al. 2016). The simulation parameters include stratigraphic ages, formation depth/thickness, erosion thickness, lithology, boundary conditions and source rock properties. The stratigraphic ages, formation depth/thickness, boundary conditions (heat flow, paleowater depth and sediment water interface temperature) and source rock properties (thickness, distribution, TOC and HI value) used the third resource evaluation results of Dongpu Depression. The erosion thickness was obtained using the vitrinite reflectance and sonic log methods (Lu et al. 2007). The porosity-depth curves of sandstones and mudstones are fitted according to the measured porosity and the porosity calculated from sonic logs, which have been used in the compaction correction of the simulation. The simulation results were calibrated and 


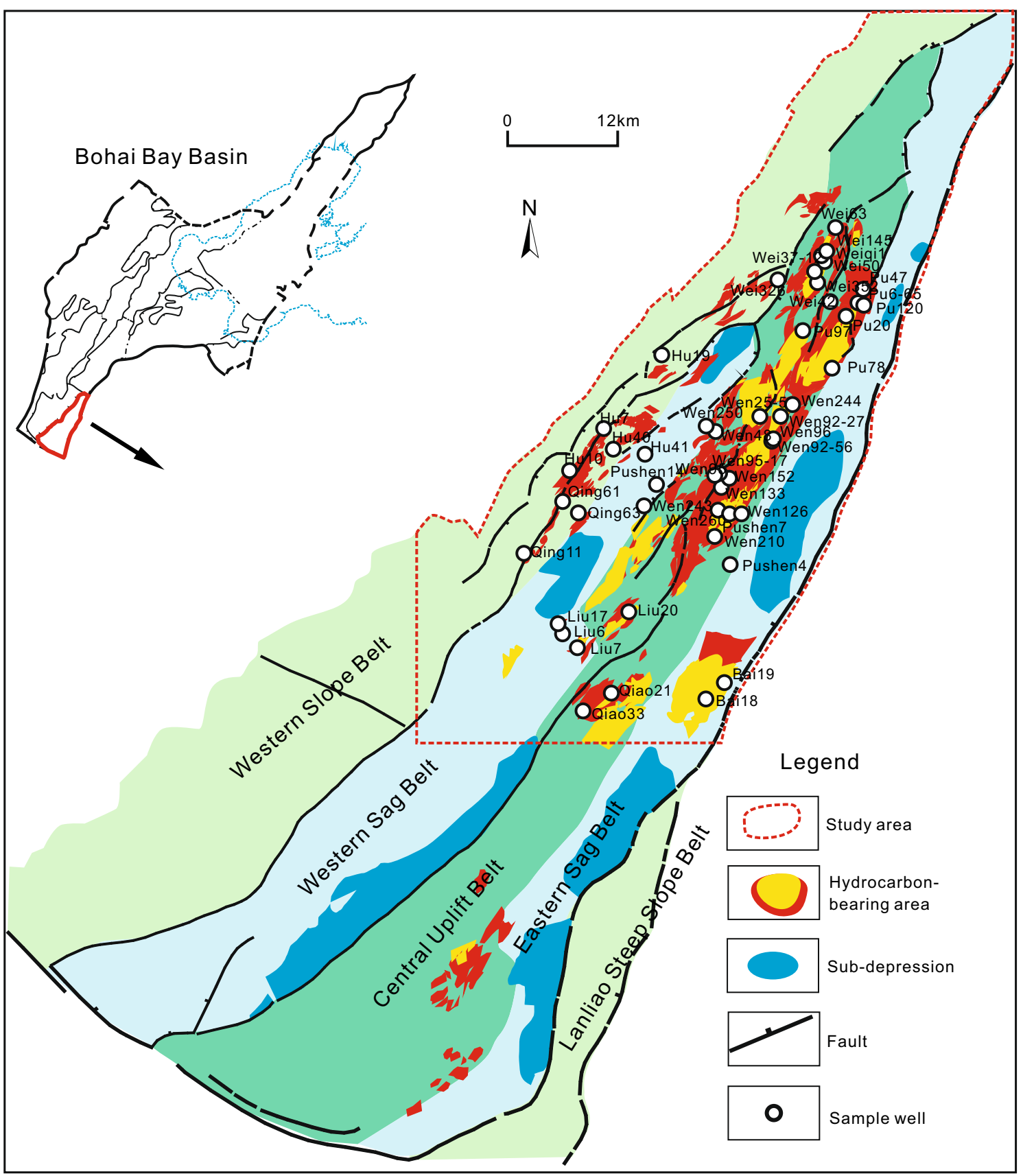

Fig. 1 Tectonic units division and hydrocarbon distribution of the Dongpu Depression, Bohai Bay Basin, showing the sample location

corrected using the measured temperature, pressure and vitrinite reflectance data.

\subsection{Fluorescence microscopy}

Fluorescence microscopy has been widely used in the field of biological sciences (Lin et al. 2015; Muhammad and Asifullah 2016). Since as early as the nineteenth century, it has been applied in petroleum geology research and has played an important role in the theory of petroleum origin and the search for oil and gas reservoirs (Lang et al. 2008). Fluorescence microscopy uses ultraviolet or blue light as a light source to stimulate the asphalt material in the rocks to produce visible fluorescence and can be used to observe the distribution of the petroleum asphalt directly. Different components in the petroleum such as saturated hydrocarbons, aromatic hydrocarbons, non-hydrocarbon and asphaltene will show different fluorescence under the ultraviolet or blue light excitation. Different luminous pitch contains different petroleum components and will display 
different fluorescence (Lang et al. 2008). Oil and gas reservoirs formed in different periods which have experienced different evolution processes have different components. Therefore, the hydrocarbon charging stages can be analyzed by observing the fluorescent pitch in the reservoir.

\subsection{The fluid inclusion petrography analytical method}

Fluid inclusion petrography studies the relationship between hydrocarbon inclusions and the host minerals to establish the relationship between the hydrocarbon migration, accumulation and the diagenetic evolution time. The qualitative research of the fluid inclusion petrography is mainly based on the occurrence, fluorescence characteristics and the phase state of hydrocarbon inclusions.

The key of the fluid inclusion study is the accurate division of hydrocarbon fluid inclusion formation stages. The determination of the diagenetic evolution sequence is the premise of the division of the inclusion formation stages, and the relative position of the host minerals in the diagenetic evolution sequence is the fundamental basis for the correct classification of the inclusions.

The homogenization temperature of the fluid inclusions represents the temperature when the inclusion is formed, which can determine the time of oil and gas filling combined with the buried heating history. Oil inclusions are generally not captured at natural gas saturation, but when restored to a single-phase state it is in saturation condition, so the homogenization temperature of the oil inclusion is generally lower than the trapping temperature, while the homogenization temperature of the associated water inclusions is generally close to the capture temperature. Therefore, when analyzing the oil and gas reservoir forming period, we usually use the brine inclusions.

In this study, the diagenetic evolution sequence was determined by thin-section identification; then, inclusion formation stages were divided according to the host minerals' formation sequence combined with the inclusion petrography analysis. Homogenization temperature tests were carried out for the observed hydrocarbon inclusions and their associated water inclusions. The time of formation of hydrocarbon inclusions of each phase was determined by the analysis of the homogenization temperature in conjunction with burial and thermal history, which is namely the hydrocarbon charging time.

\subsection{Instruments and samples}

In this study, a Zeiss AXIO Imager D1m digital polarized fluorescence microscope was used in the fluorescence microscopy, cast thin-section observations and inclusion thin-section observations, and a Linkam THMS600 gas- flow heating/freezing system was used in the homogenization temperature test.

The core sampling was carried out in the oil and gas intervals of the Shahejie Group of 49 wells (Fig. 1). A total of 136 inclusion thin sections were made for the fluorescence microscopic observation and the fluid inclusion studies. A total of 23 cast thin sections were made for the diagenesis research.

\section{Results and discussion}

\subsection{Hydrocarbon generation and expulsion histories}

The results of simulation of the evolution of major source rocks in study area showed that in the early sedimentary period of the second section of the Shahejie group $\left(\mathrm{Es}_{2}\right)$, all source rocks were at an immature stage and no hydrocarbon was expelled. From the $\mathrm{Es}_{1}$ period to the early Dongying period, source rocks were in the low mature stage and there was some hydrocarbon generated but only a little expelled. In the middle and late period of Dongying group (about 31-27 Ma), most of the source rocks were at the mature to highly mature stage, at the peak hydrocarbon generating and expulsion period. Some hydrocarbon was expelled at the early uplift stage (27-23 Ma). Then, the evolution of source rocks stagnated until the early Minghuazhen period in the Neogene. From the late Minghuazhen period until now (about 5-0 Ma), the burial depth and maturity of source rocks reached and exceeded that before the uplift, and the evolution of source rocks continued. This was the second stage of hydrocarbon generation and expulsion, in which the source rocks were at the high maturity stage in the upper layers and the over mature stage in the lower layers. However, the source rocks which entered into the second stage were relatively limited, mainly distributed in the deep hydrocarbon generation sags.

In conclusion, there were two hydrocarbon generation and expulsion stages in the study area. The first stage was from the middle and the late Dongying deposition period to the early uplift stage in the late Paleogene (about 31-23 Ma), and the second was from the late Minghuazhen period of Neogene to Quaternary (about 7-0 Ma). According to the hydrocarbon expulsion quantity in each stage, the first stage was the main hydrocarbon expulsion stage (Fig. 2).

\subsection{Fluorescence microscopy characteristics}

\subsubsection{Fluorescence characteristics of different types of asphalts}

A lot of carbonaceous asphalts (without fluorescent), bituminous asphalts, colloidal asphalts and oleaginous 


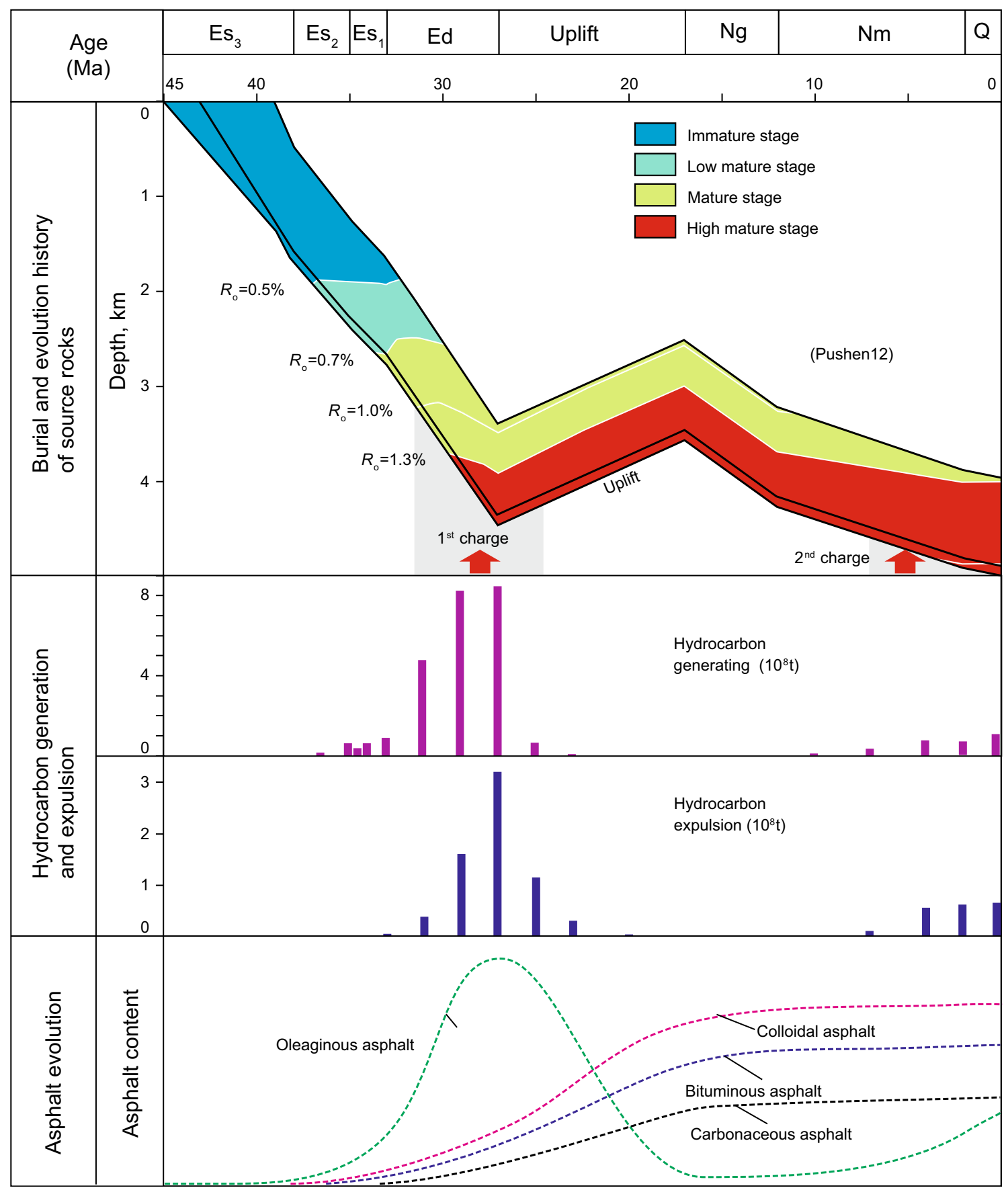

Fig. 2 Generation and expulsion history of $\mathrm{Es}_{3}$ hydrocarbon source rocks and bitumen evolution history in the Dongpu Depression

asphalts were seen in the samples of the reservoirs in the study area (Fig. 3; Table 1).

Carbonaceous asphalts are the production of petroleum alteration (Shokrlu and Babadagli 2013). These are black under both the fluorescence and transmitted light. The occurrences can be divided into three types: (1) distributed in the secondary pore spaces between the quartz particles, blocky with straight clear edges (Fig. 3a, b). (2) Distributed around the particles, ring banded or irregular shape, equivalent to the cements (Fig. 3c, d). (3) Distributed in fractures, banding (Fig. 3e, f).

The bituminous asphalts were formed due to the condensation of the resin and other heavy components of petroleum and were the residues of previous reservoirs (Qin and Guo 2002; Shalaby et al. 2012). Their main ingredients are resin, non-hydrocarbon and asphaltene, which are not soluble in petroleum ether. Bituminous asphalts are common in the samples of study area, and their 

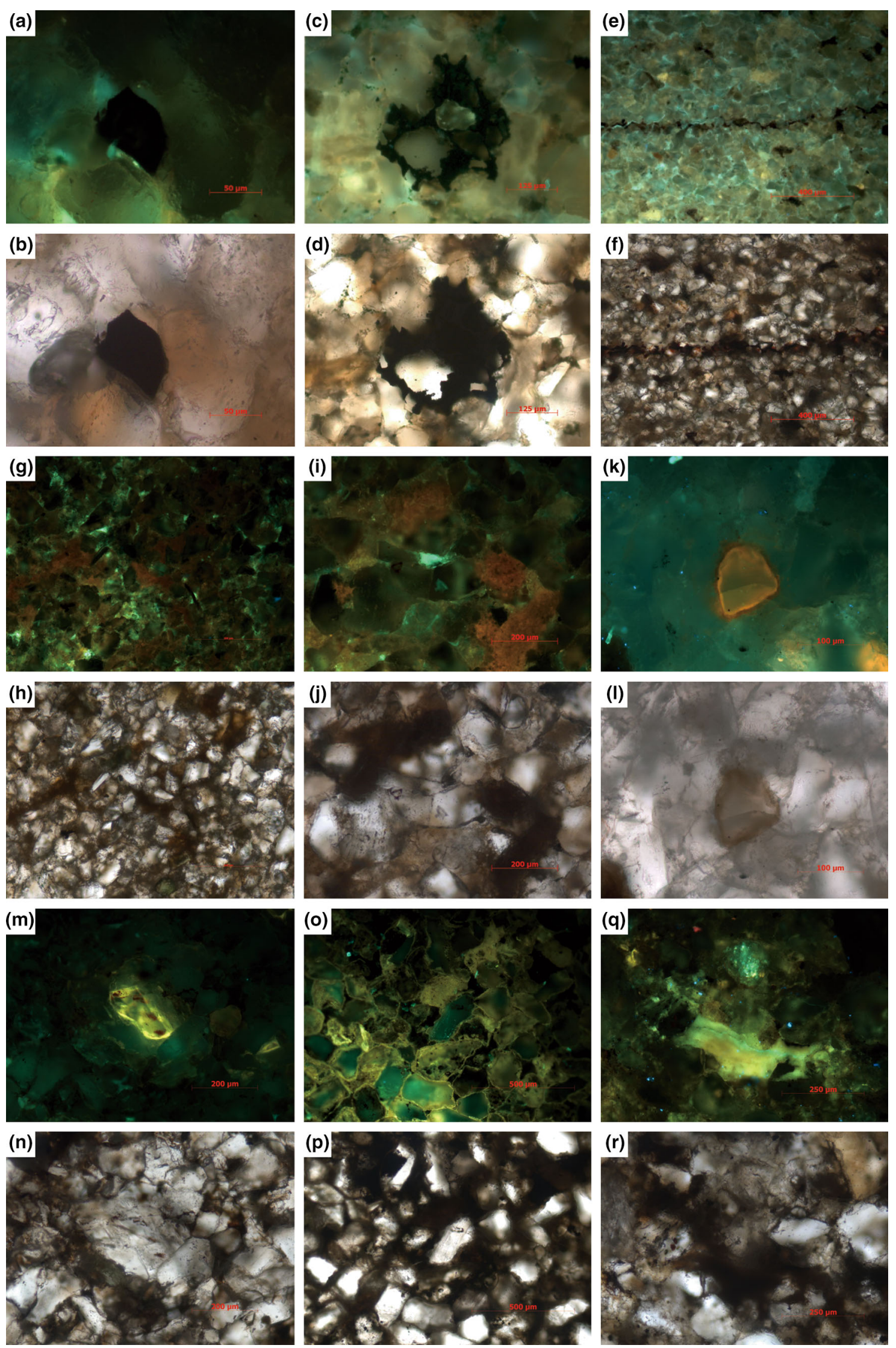
4Fig. 3 Photographs of asphalt from the northern Dongpu Depression under fluorescence and transmitted light. a-f Carbonaceous asphalt, $\mathbf{g}-\mathbf{j}$ bituminous asphalt, $\mathbf{k}-\mathbf{l}$ colloidal asphalt; $\mathbf{m}-\mathbf{r}$ oleaginous asphalt; a, b Qiao21, 2525.4 m; c, d Wei145, $2785.32 \mathrm{~m}$; e, f Wei47, 2863.78 m; g, h Hu40, 2660.3 m; i, j Qiao21, 2525.4 m; k, l Qiao59, 4556.8 m; m, n Liu6, 3882.8 m; o, p Pu120, 3264 m; q, r Pu80, $3676.05 \mathrm{~m}$

main features and occurrence can be divided into two categories: (1) distributed in the intergranular pores, with weak intensity yellow fluorescence, layered, and disseminated along both sides of the pores, gray or gray brown under transmitted light (Fig. 3g, h). (2) Clustered or blocky distributed in the intergranular pores, yellow fluorescence, dark brown under transmitted light, disseminated to the surrounding cements (Fig. 3i, j).

The colloidal asphalts were distributed on the surface of the quartz grains like films, yellow brown fluorescent, disseminated to the interior of the particles in microfractures (Fig. 3k, 1).

The oleaginous asphalts were mainly composed of light petroleum components, which were widely distributed in the reservoirs. Their occurrence can be divided into three types: (1) distributed along the calcite surface and in the cleavage cracks, yellow to yellow green fluorescence and colorless under transmitted light (Fig. 3m, n). (2) Distributed along the surface of mineral particles like thin films, yellow to yellow green fluorescence, disseminated to the interior of mineral particles (Fig. 3o, p). (3) Adsorbed in the intergranular spaces, mostly distributed in the parts where argillaceous matrix or clay mineral content is high, filling and disseminated to the matrix and matrix contraction joints, yellow green fluorescence (Fig. 3q, r).

\subsubsection{Cause analysis and phase partition of asphalts}

There are many reasons for the formation of asphalts in reservoirs. They are generally considered to be from liquid petroleum. There are 3 common reasons, which are thermal evolution, cold metamorphism and gas-washing (Luo et al. 2009). In addition to the nature of the oil, the environmental factors such as reservoir temperature, volume and pressure are very important to promote the occurrence of asphaltene deposition, and among which, pressure is the most important factor. A decrease in pressure can decrease the solubility of asphaltene in crude oil and thus cause deposition of asphalt (Qin and Guo 2002).

When the temperature of crude oil is over $150{ }^{\circ} \mathrm{C}$, it will become unstable, macromolecular hydrocarbons and other heterocyclic compounds will be gradually transformed into low molecular compounds (condensate and gas hydrocarbon) and asphalts (Guo et al. 2008). The representative geothermal gradient in the Dongpu Depression is $3.4{ }^{\circ} \mathrm{C} /$

Table 1 Distribution characteristics of reservoir bitumen in northern Dongpu Depression

\begin{tabular}{|c|c|c|c|c|c|}
\hline Area & Wells & Formation & Depth, m & Asphalt type & Phases \\
\hline \multirow{2}{*}{$\begin{array}{l}\text { Huzhuangji- } \\
\text { Qingzuji area }\end{array}$} & $\mathrm{Hu} 40$ & $\mathrm{Es}_{3}^{\mathrm{z}}$ & 2660.3 & Mainly carbonaceous and colloidal asphalts & I \\
\hline & Hu7 & $\mathrm{Es}_{3}^{\mathrm{z}}$ & 1893.8 & Mainly carbonaceous, occasionally oleaginous asphalts & I, II \\
\hline \multirow[t]{2}{*}{ Liuzhuang area } & Liu22 & $\mathrm{Es}_{2}^{\mathrm{x}}$ & 3628.4 & Mainly colloidal, bituminous and carbonaceous asphalts & I \\
\hline & Liu25 & $\mathrm{Es}_{3}^{\mathrm{s}}$ & 4140.5 & Carbonaceous, colloidal and oleaginous asphalts & I, II \\
\hline \multirow{4}{*}{$\begin{array}{l}\text { Weicheng Horst } \\
\text { zone }\end{array}$} & Wei145 & $\mathrm{Es}_{3}^{\mathrm{x}}$ & 2785.32 & Mainly carbonaceous asphalts & I \\
\hline & Wei37-12 & $\mathrm{Es}_{2}^{\mathrm{x}}$ & 2072.42 & Carbonaceous, bituminous and oleaginous asphalts & I, II \\
\hline & Wei63 & $\mathrm{Es}_{2}^{\mathrm{s}}$ & 1855.35 & Carbonaceous, colloidal, bituminous and oleaginous asphalts & I, II \\
\hline & Weiqi1 & $\mathrm{Es}_{3}^{\mathrm{s}}$ & 2560.9 & Carbonaceous, bituminous and oleaginous asphalts & I, II \\
\hline \multirow[t]{3}{*}{ Qiaokou area } & Qiao20 & $\mathrm{Es}_{3}^{\mathrm{s}}$ & 3002.3 & Carbonaceous, colloidal and oleaginous asphalts & I, II \\
\hline & Qiao21 & $\mathrm{Es}_{2}^{\mathrm{x}}$ & 2525.4 & Mainly colloidal, bituminous carbonaceous & I \\
\hline & Qiao33 & $\mathrm{Es}_{3}^{\mathrm{z}}$ & 3164.8 & Mainly oleaginous, then carbonaceous and bituminous asphalts & I, II \\
\hline \multirow[t]{3}{*}{ Baimiao area } & Bai18 & $\mathrm{Es}_{3}^{\mathrm{s}}$ & 3326.5 & Mainly colloidal and carbonaceous asphalts & I \\
\hline & Bai19 & $\mathrm{Es}_{3}^{\mathrm{x}}$ & 3891.7 & $\begin{array}{l}\text { Mainly bituminous, colloidal and oleaginous, occasionally carbonaceous } \\
\text { asphalts }\end{array}$ & I, II \\
\hline & Bai20 & $\mathrm{Es}_{2}^{s}$ & 2655.2 & Mainly carbonaceous and colloidal asphalts & I \\
\hline \multirow[t]{3}{*}{ Pucheng area } & $\mathrm{Pu} 80$ & $\mathrm{Es}_{3}^{\mathrm{z}}$ & 3673.9 & Oleaginous, colloidal and carbonaceous asphalts & I, II \\
\hline & Pu84 & $\mathrm{Es}_{3}^{\mathrm{z}}$ & 3675.8 & Carbonaceous, bituminous and oleaginous asphalts & I, II \\
\hline & Pu6-65 & $\mathrm{Es}_{3}^{\mathrm{s}}$ & 3187.6 & Carbonaceous, colloidal and bituminous asphalts & I \\
\hline \multirow[t]{3}{*}{ Wenliu area } & $\begin{array}{l}\text { Wen101- } \\
\quad 16\end{array}$ & $\mathrm{Es}_{2}^{\mathrm{x}}$ & 2304.9 & Colloidal and carbonaceous asphalts & I \\
\hline & Wen210 & $\mathrm{Es}_{3}^{\mathrm{z}}$ & 3920.25 & Carbonaceous, bituminous and colloidal asphalts & I \\
\hline & Wen244 & $\mathrm{Es}_{3}^{\mathrm{z}}$ & 3482.93 & Carbonaceous, bituminous and colloidal asphalts & I \\
\hline
\end{tabular}


$100 \mathrm{~m}$ (Liu et al. 2007a, b). The corresponding depth to reach the temperature of crude oil cracking is about $4400 \mathrm{~m}$. But most of the carbonaceous asphalts observed in the study area did not reach this depth and were not of pyrolytic origin. However, asphalts in the deep reservoir could be formed by oil cracking.

The Dongpu Depression experienced a substantial rise in the Paleogene period (27-17 Ma), the formation suffered an intense erosion, and denudation thickness was up to more than $2000 \mathrm{~m}$, with an average of about $1000 \mathrm{~m}$ (Lu et al. 2007). Strong tectonic uplift decreased the oil's burial depth and temperature and pressure became lower. Decrease in pressure caused the decrease in the solubility of asphaltene in crude oil and caused an increase in resins and bitumen and decrease in light components in the petroleum, which formed the carbonaceous asphalts, bituminous asphalts and colloidal asphalts (Fig. 2). Because of the stably distributed salt rocks in the first section of the Shahejie group and as the oil-bearing strata are mainly located under the salt rocks, the sealing and preservation condition is good, so the asphalt should not be formed by oxidation.

The above analysis indicates that carbonaceous asphalts, bituminous asphalts and colloidal asphalts were formed due to the strong uplift and erosion, which reflected the early oil and gas injection phase, while the oil and gas injected in the late period were not subjected to alteration and showed mostly oleaginous asphalts.

\subsection{Diagenetic evolution sequence}

From the detailed microscopic identification of thin sections, the diagenesis of reservoir sandstones of the Shahejie Formation in the study area mainly includes compaction, cementation, metasomatism and dissolution (Fig. 4).

According to the "Standard for the division of diagenetic stages of clastic rocks" (Ying et al. 2004), using paleotemperature, vitrinite reflectance $\left(R_{\mathrm{o}}\right)$ and authigenic clay mineral assemblages, the diagenetic stages of sandstones of the Shahejie Formation in the northern Dongpu Depression were divided into the early diagenetic stage B, middle diagenetic phase $\mathrm{A}$ and middle diagenetic phase $\mathrm{B}$. The schematic diagram of diagenetic stages division of the reservoirs of the Shahejie Formation in the northern Dongpu Depression was compiled (Fig. 5). The characteristics of each diagenetic stages are as follows.

The early diagenetic stage B: depth from 2000 to $2500 \mathrm{~m}$, temperature $<95{ }^{\circ} \mathrm{C}, R_{\mathrm{O}}<0.5 \%$, equivalent to the semimature period of the organic matter evolution, and the smectite layer of I/S mix-layer was in the second quick transformation zone (from $50 \%$ to $20 \%$ ). In this stage, the diagenesis was dominated by compaction and early carbonate cementation. The cementation included calcite cementation, secondary outgrowth of quartz and the precipitation of dolomite.
The middle diagenetic phase A1: depth from 2500 to $3300 \mathrm{~m}$, temperature from 95 to $135{ }^{\circ} \mathrm{C}, R_{\mathrm{o}}$ from $0.5 \%$ to $0.7 \%$, in the low mature stage of organic matter evolution. In this stage, the main diagenesis included dolomite cementation, ferroan dolomite cementation and clastic particles replacement by calcite, calcite replacement by ferroan calcite and the dissolution of quartz and feldspar particles in the later stage.

The middle diagenetic phase A2: depth from 3300 to $4200 \mathrm{~m}$, temperature from 135 to $160{ }^{\circ} \mathrm{C}$, vitrinite reflectance $R_{\mathrm{o}} 0.7 \%$ to $1.3 \%$, in the mature stage of organic matter. This stage was characterized by a large amount of dolomite and ferroan dolomite cementation, and the dissolution of quartz and feldspar.

The middle diagenetic stage B: burial depth of 4200 to $5000 \mathrm{~m}$, temperature of $>160{ }^{\circ} \mathrm{C}$, vitrinite reflectance $R_{\mathrm{O}}>1.3 \%$, the main features of this stage are the secondary outgrowth of quartz and the metasomatism of ferroan dolomite.

Microfractures are important places to capture fluid inclusions. Understanding the cause of the microfractures and their formation sequence in the diagenetic stage is the basis for determining the phase of hydrocarbon inclusions in the microfractures. Microfractures containing hydrocarbon inclusions in the study area include the internal cracks of quartz particles (Fig. 6e, f), and the cracks through quartz grains (Fig. 6i-1). The former did not cut through the quartz grains and the latter cut through the whole quartz grains. Research suggests that the internal cracks of quartz particles were formed due to the pressure of the overlying strata exceeding the critical fracture pressure of the debris particles (Li et al. 2014). These fractures had been gradually healed due to late diagenesis. In the samples, the internal cracks of quartz appeared at depths below $2500 \mathrm{~m}$, which is equivalent to the middle diagenetic phase A1 and the later diagenetic stages. The cracks through quartz grains appeared in the whole section, not controlled by the depth. This indicates that the cracks through quartz grains should not be the result of diagenesis and presumably be formed due to the stress field changes caused by the tectonic uplift during late Paleogene, which captured the fluid inclusions during the subsidence in the Quaternary period.

\subsection{Characteristics of fluid inclusion petrography}

\subsubsection{Fluid inclusion petrography}

Generally speaking, petroleum inclusions formed in the low mature phase of hydrocarbon source rock evolution had a high density, with a high content of heavy hydrocarbon and asphaltene. And their fluorescence is mainly brown. As the maturity increases, or the migration and 

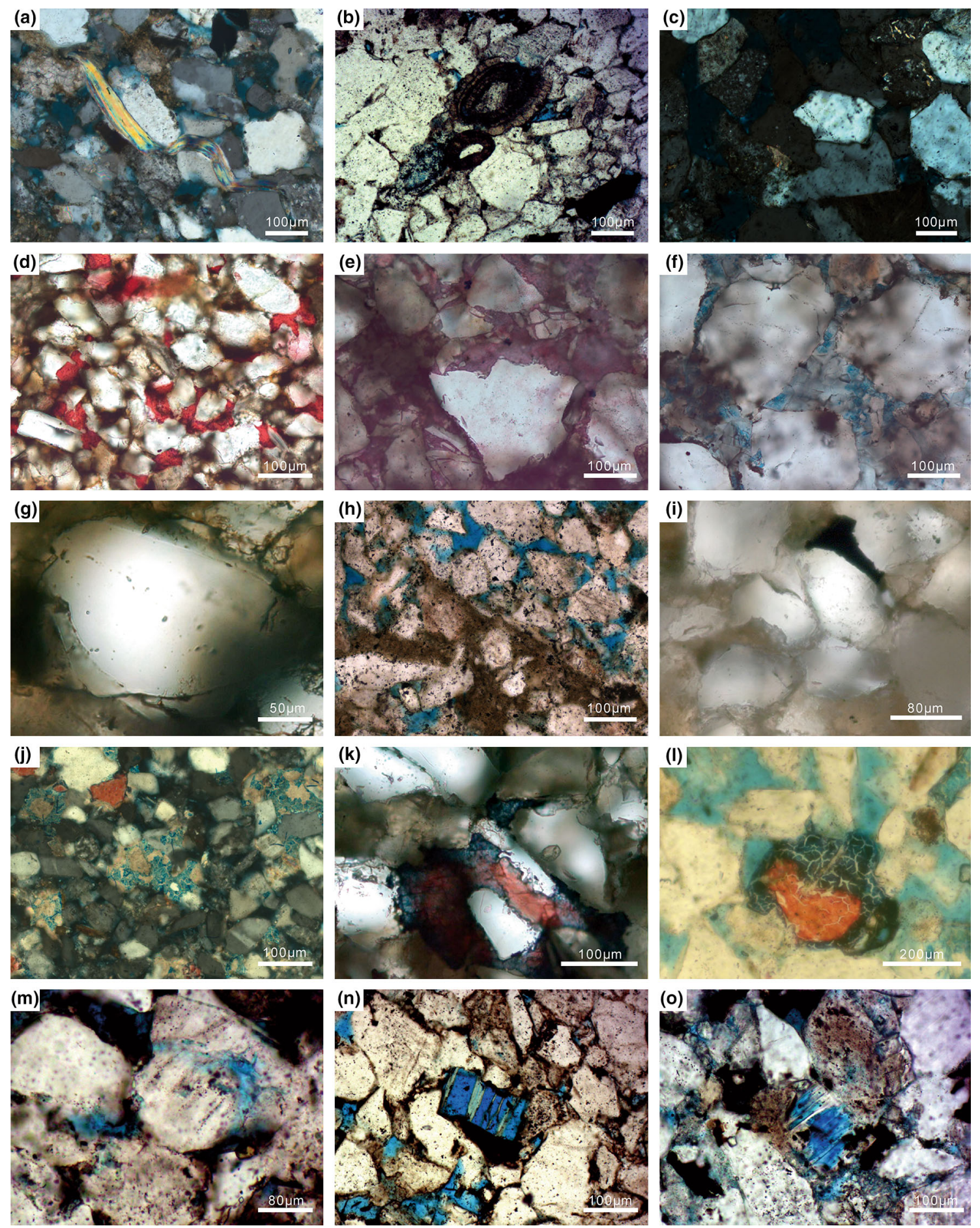

Fig. 4 Diagenesis of the Shahejie Formation in the northern Dongpu Depression. a Mica is extruded and deformed, Wen126, 2922.6 m; b Oolite deformation, Pushen7, $3696.7 \mathrm{~m}$; c lined and concavo-convex intergranular contacts, Wen92-27, $2825.6 \mathrm{~m}$; d calcite cementation, Wei327, $2511 \mathrm{~m}$; e ferroan calcite cementation, Wei57, $2712.7 \mathrm{~m}$; f dolomite and ankerite cement, Qing61, 2880.8 m; g quartz overgrowth, Liu6, $3882.8 \mathrm{~m}$; $\mathbf{h}$ argillaceous cementation, Wen126, $2922.6 \mathrm{~m}$; $\mathbf{i}$ asphalt cementation, Wen25-5, $2284.9 \mathrm{~m}$; $\mathbf{j}$ ferroan dolomite replaces dolomite cements, Hu40, $2664.64 \mathrm{~m}$; k ferroan dolomite replaces calcite cements, Hu64, $3410 \mathrm{~m}$; l calcite replaces particles, ferroan calcite replaces calcite, Hu40, $2664.64 \mathrm{~m}$; m quartz was dissolved, Wen243, $4273.5 \mathrm{~m}$; n feldspar was dissolved along the cleavage, Pushen7, $3696.7 \mathrm{~m}$; o feldspar was dissolved, Liu7, $3525.3 \mathrm{~m}$ 


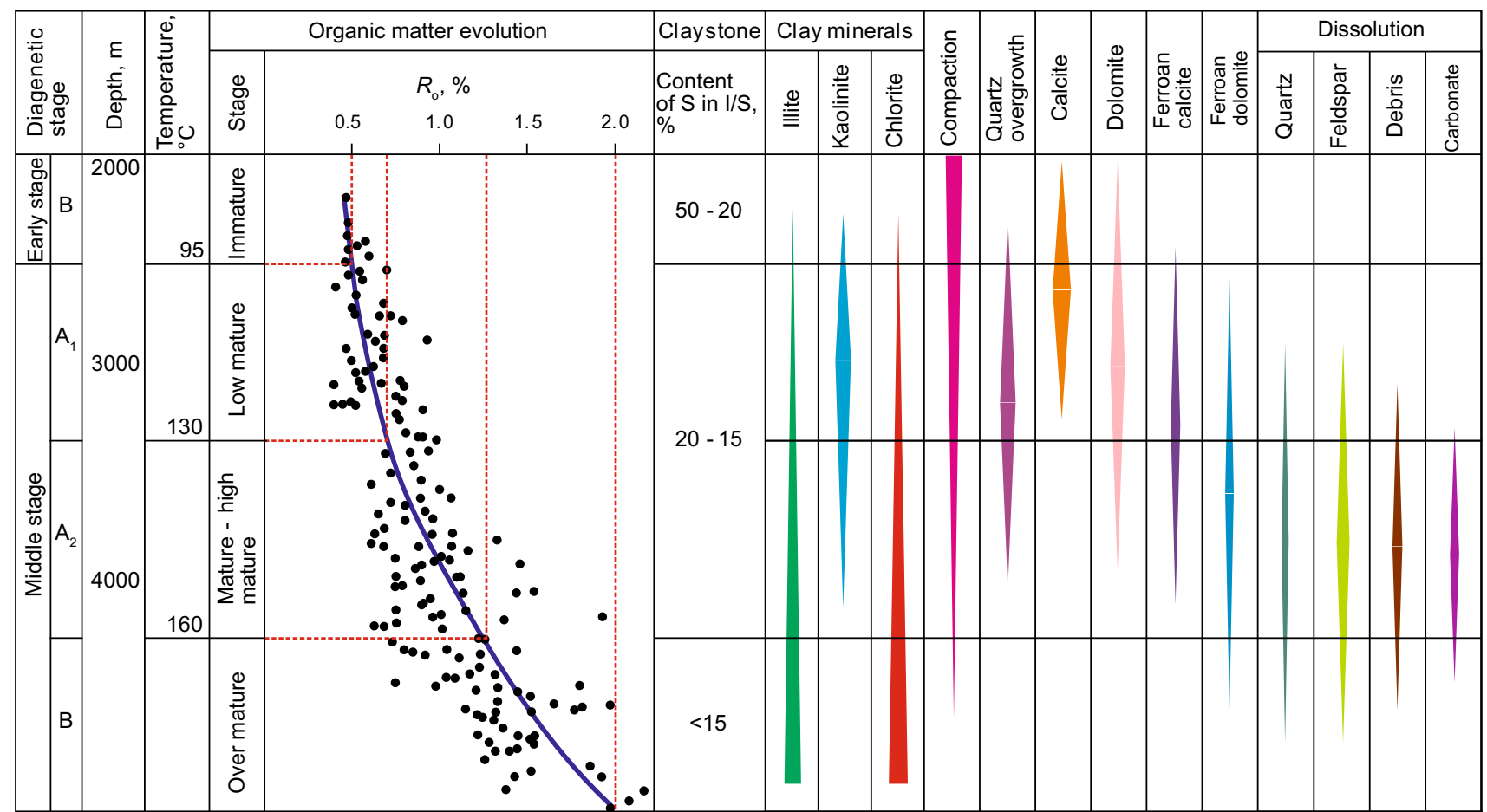

Fig. 5 Diagenetic stages of the Shahejie Formation in the northern Dongpu Depression
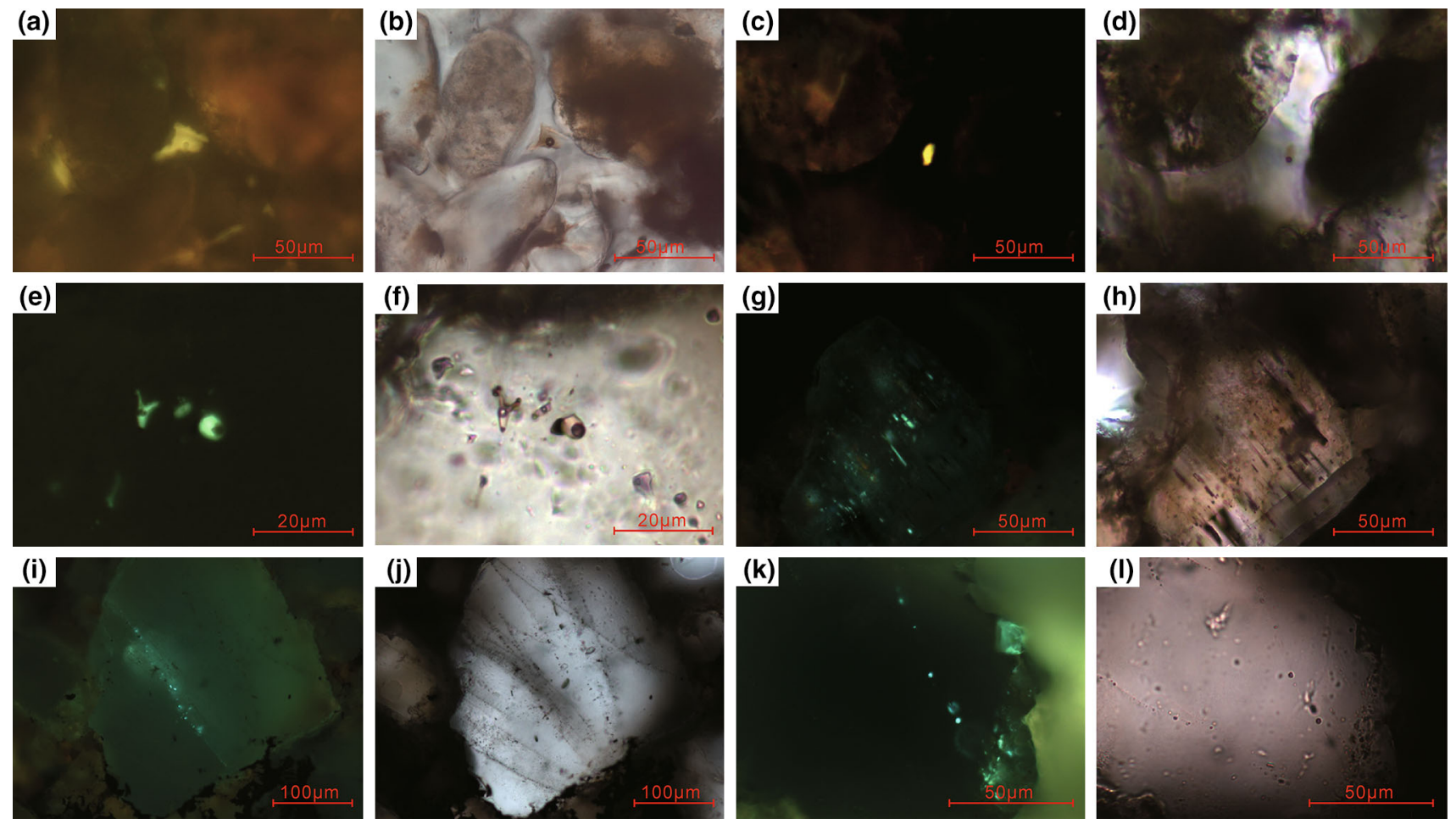

Fig. 6 Inclusion photographs under fluorescence and transmitted light of northern Dongpu Depression. a, b Inclusions occurred in calcite cements, Wen25-5, $2282.8 \mathrm{~m}$; c, d inclusions occurred in ferroan calcite cements, Hu40, $2660.3 \mathrm{~m}$; e, $\mathbf{f}$ inclusions occurred in fractures within quartz grains, Pu47, $3039.49 \mathrm{~m} ; \mathbf{g}, \mathbf{h}$ inclusions occurred in dissolution fractures of feldspar, Wen88-1, $3603.38 \mathrm{~m}$; $\mathbf{i}$, j inclusions occurred in fractures through the quartz grains, Hu10, $2233.9 \mathrm{~m} ; \mathbf{k}, \mathbf{l}$ inclusions occurred in fractures through the quartz grains, Weiqi1, $2658.05 \mathrm{~m}$ 
differentiation increased, crude oil density became low, and fluorescence colors of the petroleum inclusions captured in this stage are mainly white, yellow or yellow green. Petroleum inclusions formed in the highly mature phase have fluorescence colors mainly milky blue or blue (Liu et al. 2007a, b). Fluorescent colors of hydrocarbon inclusions observed in the study area include yellow, yellowish white, yellow green and blue white, which indicates that the oil and gas in the study area were mainly charged at mature and highly mature stages (Fig. 6).

Hydrocarbon inclusions in the study area are mainly gas-liquid two-phase inclusions, mainly distributed in the carbonate cements (including calcite dolomite and ferroan dolomite), feldspar dissolution pores, internal cracks in quartz grains and late cracks through quartz grains (Fig. 6).

\subsubsection{Phase division of fluid inclusions}

According to the analysis of diagenetic evolution sequence, the calcite and dolomite were early carbonate cements, formed in the early diagenetic stage B, when the reservoir depth was up to $2000 \mathrm{~m}$. The ferroan dolomite was late carbonate cement formed in the middle diagenetic A phase, when the reservoir was buried below $2500 \mathrm{~m}$. The internal cracks of quartz grains were formed in the middle diagenetic phase A1, when buried deep below $2500 \mathrm{~m}$. The feldspar dissolution pores and fractures were the result of feldspar dissolution, which happened in the late period of middle diagenetic phase A1, when buried below $3000 \mathrm{~m}$. The cracks through quartz grains were formed after the uplift in the late Paleogene.

The hydrocarbon inclusions in different minerals or fractures distributed in different depths: The inclusion in the carbonate cements distributed at depths of 2000-2700 m, among which the early carbonate cements distributed at 2000-2500 m and the late carbonate cements in $2500-2700 \mathrm{~m}$. The inclusions in the internal cracks of quartz grains distributed at depths of $2500-4000 \mathrm{~m}$, and inclusions in the feldspar dissolution pores and fractures of the quartz grains are distributed at $3100-4000 \mathrm{~m}$. Inclusions in the cracks through quartz grains are distributed in all depths.

Samples of different depths have different burial histories. The geological periods corresponding to the diagenetic stages of the host minerals are estimated in the reservoir burial history, from the time of formation of different host minerals of hydrocarbon inclusions (Fig. 7). The results show that the inclusions in the carbonate

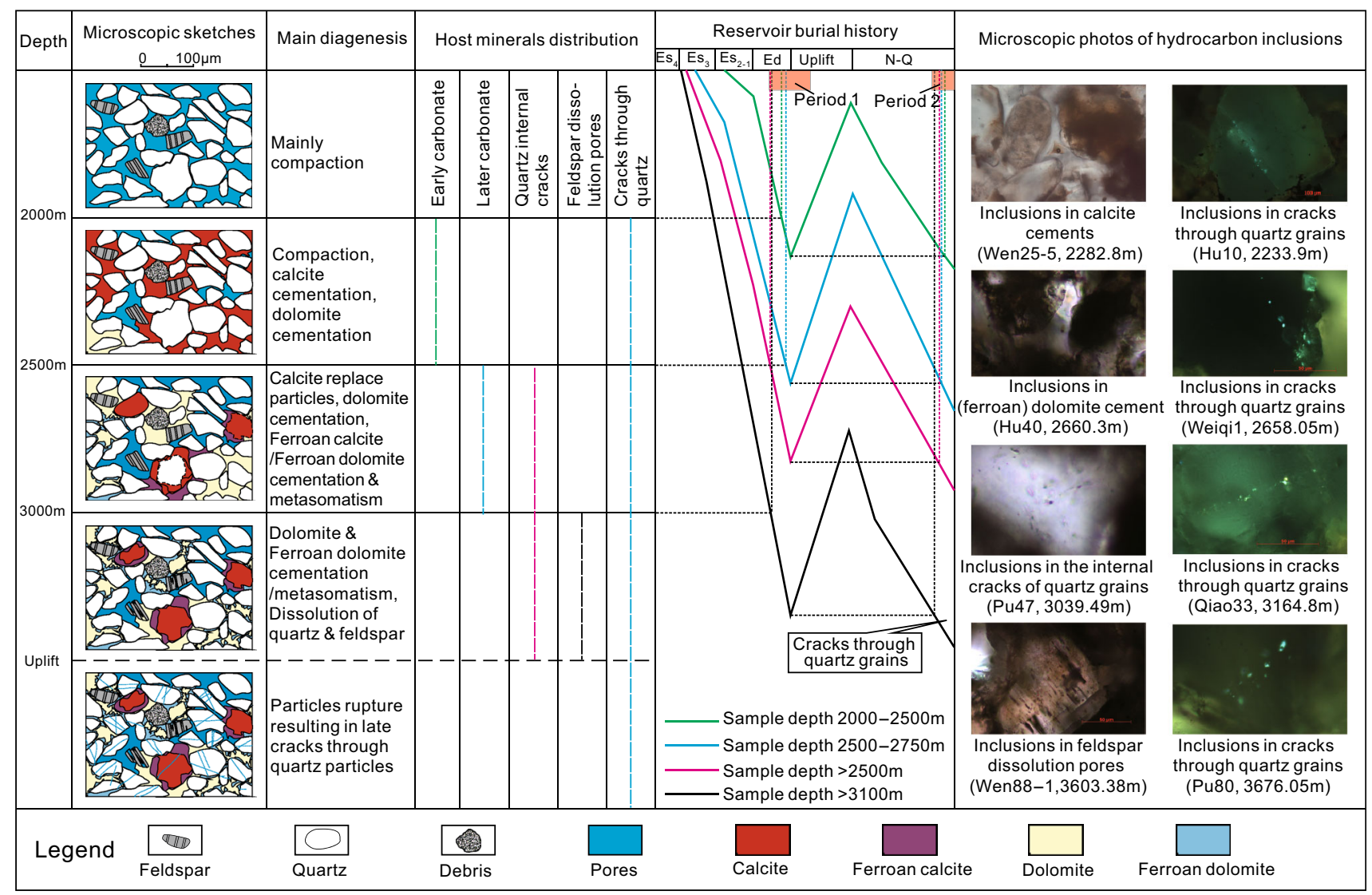

Fig. 7 Using diagenetic stages and burial history to determine the time of formation of hydrocarbon inclusions in the North Dongpu Depression 
Formation temperature, ${ }^{\circ} \mathrm{C}$

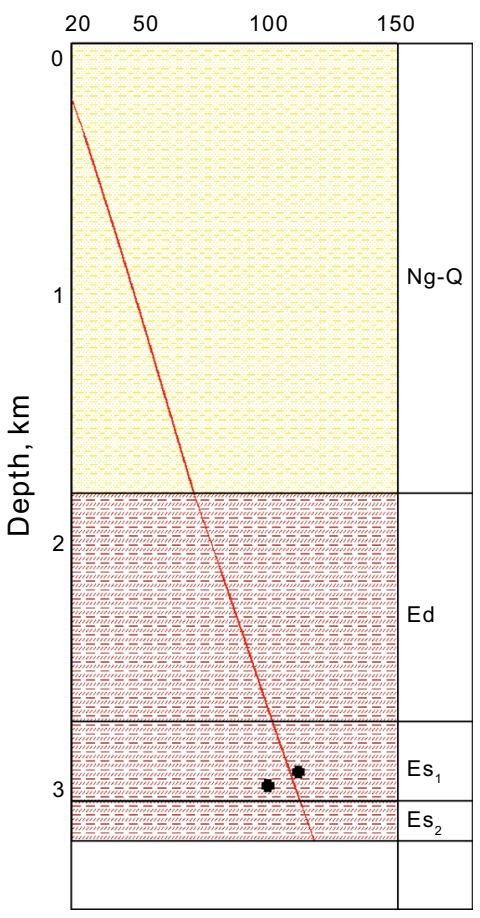

$R_{\mathrm{o}}, \%$

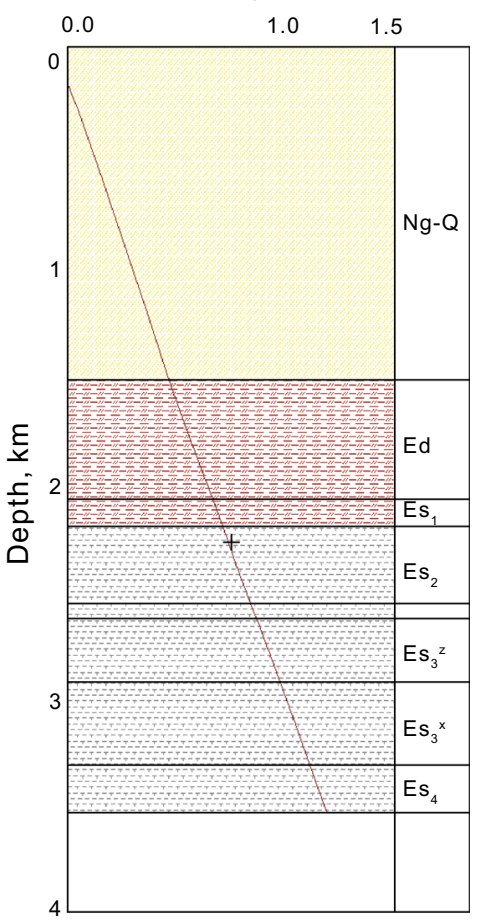

Age, Ma

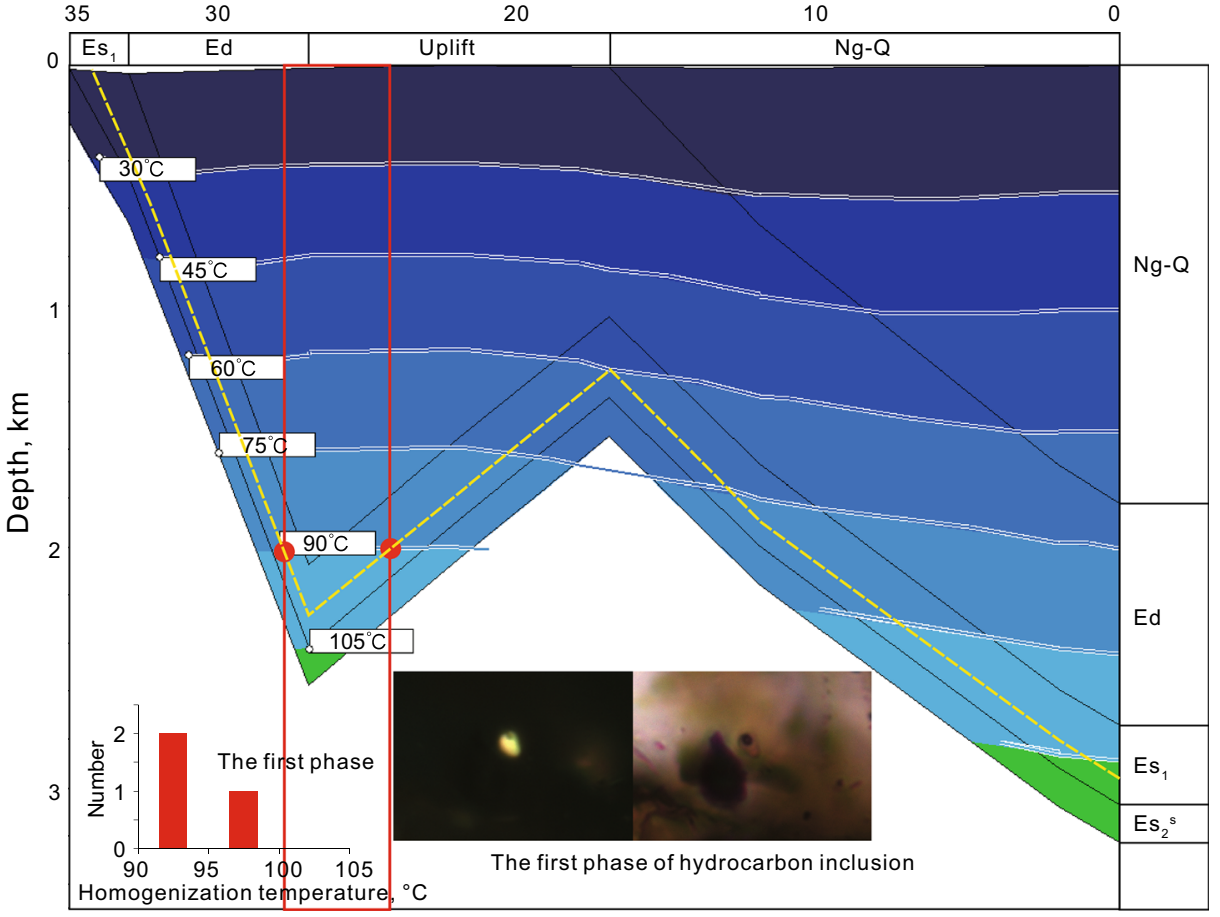

(a) Liu17, 2959.15m

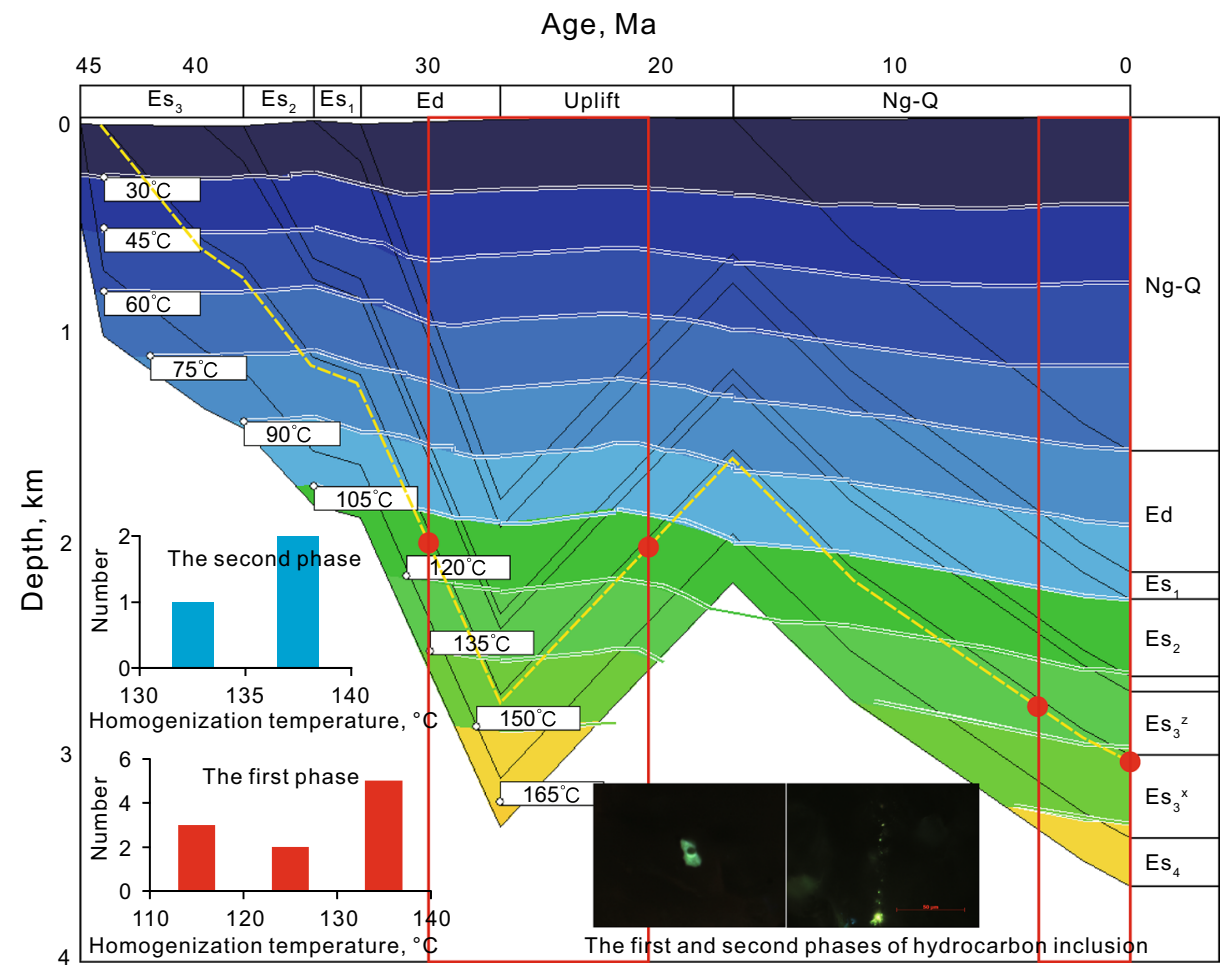

(b) Qiao 33, 3442.3m

Fig. 8 Hydrocarbon accumulation time determined by homogenization temperature combined with geothermal and burial history 
Table 2 Characteristics of fluid inclusions and hydrocarbon accumulation time in different areas in the northern Dongpu Depression, Bohai Bay Basin

\begin{tabular}{|c|c|c|c|c|c|c|c|}
\hline Area & Tectonic belt & Well & Formation & Depth, m & Phases & $\begin{array}{l}\text { Associated brine } \\
\text { inclusion } \\
\text { homogenization } \\
\text { temperature, }{ }^{\circ} \mathrm{C}\end{array}$ & $\begin{array}{l}\text { Hydrocarbon } \\
\text { charge time, Ma }\end{array}$ \\
\hline \multirow{23}{*}{$\begin{array}{l}\text { Wenliu-Liuzhuang } \\
\text { area }\end{array}$} & Eastern sag belt & Pushen4 & $\mathrm{Es}_{3}^{\mathrm{s}}$ & 3703.2 & I, II & $105-130,125-130$ & $30-27,5-0$ \\
\hline & \multirow[t]{2}{*}{ Western sag belt } & Pushen14 & $\mathrm{Es}_{3}^{\mathrm{s}}$ & 3983.9 & I, II & $140-155,135-145$ & $28.8-23.8,5-0$ \\
\hline & & Wen243 & $\mathrm{Es}_{3}^{\mathrm{z}}$ & 4273.5 & I, II & $140-155,150-160$ & $30.5-28.8,5.5-0$ \\
\hline & Wenxi fault zone & Wen250 & $\mathrm{Es}_{3}^{\mathrm{z}}$ & 3605.8 & I & $120-135$ & $30.5-28.8$ \\
\hline & \multirow{3}{*}{$\begin{array}{l}\text { Wendong graben } \\
\text { zone }\end{array}$} & Wen260 & $\mathrm{Es}_{3}^{\mathrm{z}}$ & 3577.7 & I & $105-135$ & $30.9-27.8$ \\
\hline & & Wen 133 & $\mathrm{Es}_{2}$ & 2903.3 & $\mathrm{I}$ & $110-125$ & $31.6-29.8$ \\
\hline & & Wen 152 & $\mathrm{Es}_{3}^{\mathrm{s}}$ & 3194 & I & $105-120$ & $29.2-28$ \\
\hline & \multirow{3}{*}{$\begin{array}{l}\text { Wenzhong Horst } \\
\text { zone }\end{array}$} & Wen 48 & $\mathrm{Es}_{2}$ & 2548.59 & I & $100-120$ & $29-23.5$ \\
\hline & & Wen95 & $\mathrm{Es}_{3}^{\mathrm{z}}$ & 2753.9 & I & $85-110$ & $29.2-24$ \\
\hline & & Wen95-17 & $\mathrm{Es}_{3}^{\mathrm{Z}}$ & 2876.75 & I & $90-110$ & $29.4-23.2$ \\
\hline & \multirow{5}{*}{$\begin{array}{l}\text { Wendong rolling } \\
\text { anticlinal zone }\end{array}$} & Wen244 & $\mathrm{Es}_{3}^{\mathrm{z}}$ & 3477.6 & I & $120-130$ & $29.8-28.8$ \\
\hline & & Wen25-5 & $\mathrm{Es}_{2}$ & 2282.8 & I & $85-100$ & $29.5-28$ \\
\hline & & Wen92-27 & $\mathrm{Es}_{3}^{\mathrm{s}}$ & 2825.6 & $\mathrm{I}$ & $95-110$ & $28.8-24.8$ \\
\hline & & Wen92-56 & $\mathrm{Es}_{3}^{\mathrm{s}}$ & 2748.45 & I & $90-110$ & $28.3-25.1$ \\
\hline & & Wen96 & $\mathrm{Es}_{2}$ & 2524.55 & I & $80-100$ & $28.7-23.6$ \\
\hline & \multirow{4}{*}{$\begin{array}{l}\text { Wendong reverse } \\
\text { roof ridge zone }\end{array}$} & Pushen7 & $\mathrm{Es}_{3}^{\mathrm{s}}$ & 4156.9 & $\mathrm{I}$ & $115-135$ & $32.2-29.9$ \\
\hline & & Pushen7 & $\mathrm{Es}_{3}^{\mathrm{z}}$ & 3696.7 & I, II & $80-135,120-140$ & $32.5-27,7.5-0$ \\
\hline & & Wen126 & $\mathrm{Es}_{2}$ & 2922.6 & I, II & $100-120,95-110$ & $28.4-23.3,6-0$ \\
\hline & & Wen210 & $\mathrm{Es}_{3}^{\mathrm{z}}$ & 3920.25 & I & $120-135$ & $30.5-29.2$ \\
\hline & \multirow[t]{4}{*}{ Liuzhuang area } & Liu17 & $\mathrm{Es}_{1}$ & 2959.15 & I & $90-100$ & $28-24.5$ \\
\hline & & Liu20 & $\mathrm{Es}_{2}$ & 3554.2 & $\mathrm{I}$ & $100-130$ & $30.6-28$ \\
\hline & & Liu6 & $\mathrm{Es}_{3}^{\mathrm{s}}$ & 3882.8 & I, II & $120-140,125-140$ & $29.5-27,7-2.5$ \\
\hline & & Liu7 & $\mathrm{Es}_{2}$ & 3525.3 & I, II & $110-1252,10-135$ & $29.8-28.4,5.4-0$ \\
\hline \multirow{14}{*}{$\begin{array}{l}\text { Pucheng-Weicheng } \\
\text { area }\end{array}$} & \multirow{6}{*}{$\begin{array}{l}\text { Pucheng reverse roof } \\
\text { ridge zone }\end{array}$} & Pu120 & $\mathrm{Es}_{3}^{\mathrm{s}}$ & 3054.3 & I & $110-120$ & $29.3-28$ \\
\hline & & Pu120 & $\mathrm{Es}_{3}^{\mathrm{z}}$ & 3264 & II & $120-135$ & $6-0$ \\
\hline & & Pu20 & $\mathrm{Es}_{2}$ & 2756.5 & I, II & $90-130,100-115$ & $30.5-27,5-0$ \\
\hline & & $\mathrm{Pu} 47$ & $\mathrm{Es}_{3}^{\mathrm{s}}$ & 3104.53 & I & $110-115$ & $29.5-27.8$ \\
\hline & & Pu6-65 & $\mathrm{Es}_{3}^{\mathrm{s}}$ & 3108.25 & $\mathrm{I}$ & $120-130$ & $28.4-24$ \\
\hline & & Pu78 & $\mathrm{Es}_{3}^{\mathrm{s}}$ & 3279.25 & I, II & $105-125,310-140$ & $30-28.6,6.5-0$ \\
\hline & \multirow[t]{8}{*}{ Weicheng Horst zone } & $\mathrm{Pu} 97$ & $\mathrm{Es}_{3}^{\mathrm{s}}$ & 3120 & I, II & $120-140,105-120$ & $29-27,5-0$ \\
\hline & & Wei145 & $\mathrm{Es}_{3}^{\mathrm{s}}$ & 2785.32 & $\mathrm{I}$ & $135-150$ & $28.1-25$ \\
\hline & & Wei352 & $\mathrm{Es}_{2}$ & 2252.6 & I, II & $80-105,70-110$ & $29.5-27.5,3.5-0$ \\
\hline & & Wei37-12 & $\mathrm{Es}_{2}$ & 2072 & $\mathrm{I}, \mathrm{II}$ & $80-100,75-90$ & $29.2-27.5,4.5-0$ \\
\hline & & Wei42 & $\mathrm{Es}_{3}^{\mathrm{z}}$ & 3446 & I, II & $125-135,115-130$ & $29.5-28,4.5-0$ \\
\hline & & Wei50 & $\mathrm{Es}_{3}^{\mathrm{s}}$ & 2737 & I, II & $120-130,95-100$ & $27.8-25.7,4.2-0$ \\
\hline & & Wei63 & $\mathrm{Es}_{2}$ & 1860 & I, II & $80-90,56-80$ & $28-25,2.3-0$ \\
\hline & & Weiqi1 & $\mathrm{Es}_{3}^{\mathrm{s}}$ & 2660 & I, II & $115-130,100-110$ & $29.4-27.8,3.6-0$ \\
\hline \multirow[t]{9}{*}{ Western slope belt } & Mazhai & Wei326 & $\mathrm{Es}_{3}^{\mathrm{s}}$ & 3344.8 & I, II & $115-135,105-120$ & $31-29,8.5-2$ \\
\hline & Xinzhuang & Hu19 & $\mathrm{Es}_{3}^{\mathrm{z}}$ & 1820 & I & $90-120$ & $28.8-24.5$ \\
\hline & \multirow{7}{*}{$\begin{array}{l}\text { Huzhuangji-Qingzuji } \\
\text { Area }\end{array}$} & Hu7 & $\mathrm{Es}_{3}^{\mathrm{z}}$ & 1892.6 & I, II & $80-95$ & $28.8-24.8$ \\
\hline & & $\mathrm{Hu} 40$ & $\mathrm{Es}_{3}^{\mathrm{z}}$ & 2660.3 & I & $90-105$ & $30.5-28.5$ \\
\hline & & $\mathrm{Hu} 41$ & $\mathrm{Es}_{3}^{\mathrm{z}}$ & 3888.4 & I & $150-170$ & $29.2-23.1$ \\
\hline & & $\mathrm{Hu} 10$ & $\mathrm{Es}_{3}^{\mathrm{s}}$ & 2233.9 & I, II & $90-100,105-130$ & $30.7-29,3.6-0$ \\
\hline & & Qing61 & $\mathrm{Es}_{3}^{\mathrm{s}}$ & 2880.8 & $\mathrm{I}$ & $95-130$ & $30-22.2$ \\
\hline & & Qing63 & $\mathrm{Es}_{3}^{\mathrm{s}}$ & 3144 & I, II & $130-135,120-130$ & $28.2-26.3,6-0$ \\
\hline & & Qing11 & $\mathrm{Es}_{3}^{\mathrm{s}}$ & 2382 & I, II & $90-110,90-120$ & $29.2-23.7,7-0$ \\
\hline
\end{tabular}


Table 2 continued

\begin{tabular}{|c|c|c|c|c|c|c|c|}
\hline Area & Tectonic belt & Well & Formation & Depth, m & Phases & $\begin{array}{l}\text { Associated brine } \\
\text { inclusion } \\
\text { homogenization } \\
\text { temperature, }{ }^{\circ} \mathrm{C}\end{array}$ & $\begin{array}{l}\text { Hydrocarbon } \\
\text { charge time, Ma }\end{array}$ \\
\hline \multirow{4}{*}{$\begin{array}{l}\text { Qiaokou-Baimiao } \\
\text { area }\end{array}$} & \multirow[t]{2}{*}{ Baimiao } & Bai18 & $\mathrm{Es}_{3}^{\mathrm{s}}$ & 3326.5 & I & $100-140$ & $31.5-28$ \\
\hline & & Bai19 & $\mathrm{Es}_{3}^{\mathrm{s}}$ & 3891.7 & I, II & $100-120,100-130$ & $31.5-29,7-0$ \\
\hline & \multirow[t]{2}{*}{ Qiaokou } & Qiao21 & $\mathrm{Es}_{2}$ & 2525 & I & $95-110$ & $28-25.4$ \\
\hline & & Qiao33 & $\mathrm{Es}_{3}^{\mathrm{z}}$ & 3164 & I, II & $110-140,130-140$ & $30-27,4-0$ \\
\hline
\end{tabular}

cements, internal cracks of quartz grains and feldspar dissolution pores were formed in the late Dongying deposition period, and they were formed in the same period. The hydrocarbon inclusions occurred in the cracks through quartz grains were formed in the reburial period after the tectonic uplift, the second phase of hydrocarbon inclusions. Therefore, the hydrocarbon inclusions can be divided into two phases, which reflects the two hydrocarbon accumulation processes, the main characteristics of each stage of the hydrocarbon inclusions are as follows.

The first phase of hydrocarbon inclusions is distributed in carbonate cements, internal cracks of quartz grains and feldspar dissolution pores which are gas-liquid two-phase hydrocarbon inclusions with sliver shape or irregular shape, isolated or sporadic distribution, variable size, yellow, yellowish white or yellowish green fluorescence, and brown, light brown or colorless under transmitted light. They correspond with the early oil and gas filling (Fig. 6a-h).

The second phase of hydrocarbon inclusions occurs in cracks through quartz grains in a beaded distribution, with ellipse shapes, usually small, yellow green to bluish green in fluorescence, colorless under transmitted light. They correspond to the late highly mature stage of oil and gas filling (Fig. 6i-1).

\subsection{Inclusion homogenization temperature characteristics and determination of hydrocarbon accumulation timing}

The time of formation of hydrocarbon inclusions of different phases was determined by the combined analysis of homogenization temperature and reservoir burial heating history (Fig. 8). The homogenization temperature of fluid inclusions was tested, and the hydrocarbon charge period was determined in different tectonic units and different layers in this study (Table 2).

Based on the comprehensive analysis of hydrocarbon generation and expulsion histories of major source rocks, fluorescence microscopic characteristics and reservoir fluid inclusions, the pool-forming period was divided into two phases: The first phase is from late Dongying deposition period to the early uplift stage in late Oligocene and the second is from late Minghuazhen deposition period in Pliocene to Quaternary. The first period is the main accumulation period.

By comparing the pool-forming time in different tectonic belts and different oil and gas bearing series, it can be seen that the first stage of hydrocarbon accumulation occurs widely, distributed in the whole region, and the second stage of the hydrocarbon reservoirs was mainly distributed near the sub-depressions, including the Puwei sag belt, Huqing area, Qiaokou and Baimiao area, Wendong area, the south of Wenxi area, the west of Liuzhuang area, Qianliyuan sub-sag and Haitongji sub-depression. The central uplift belt and the western slope zone of northern Xinzhuang, Mazhai, and the distant-free hydrocarbon accumulation area only have the first stage of poolforming. In the vertical direction, the first stage is widely distributed in a large depth span, mainly distributed in the depth range of 2000-3500 m. From the view of layers, there was a single stage in the upper layers and two stages in lower layers. Specifically, the second section of the Shahejie group and the upper and middle layers of the third section of the Shahejie group were mainly in the first stage, while the lower part of the third section of the Shahejie group was in two stages (Fig. 9).

The difference of the hydrocarbon charge history in different parts and different layers is closely related to fault activity. The fault system is highly developed in the Dongpu Depression and is the main channel for oil and gas migration. The activity rate of the main secondary oil source faults was calculated using the fault activity rate method (Table 3). The main oil source faults in the study area became active in the early stage of $\mathrm{Es}_{3}$. The activity rate was the highest in the late $\mathrm{Es}_{3}$ and $\mathrm{Es}_{2}$ and decreased gradually in the $\mathrm{Es}_{1}$ and Dongying period. The rate of fault activity could not be calculated during the uplift period because there is no sediment, but the tectonic movement in this period is very intense, and it is inferred that most faults are active. Most of the faults have not cut through the Guantao Formation, so that most of the fault activity stopped in the Early Neogene.

In the first stage of oil and gas accumulation, the source of oil and gas was abundant, and the fault activity was 

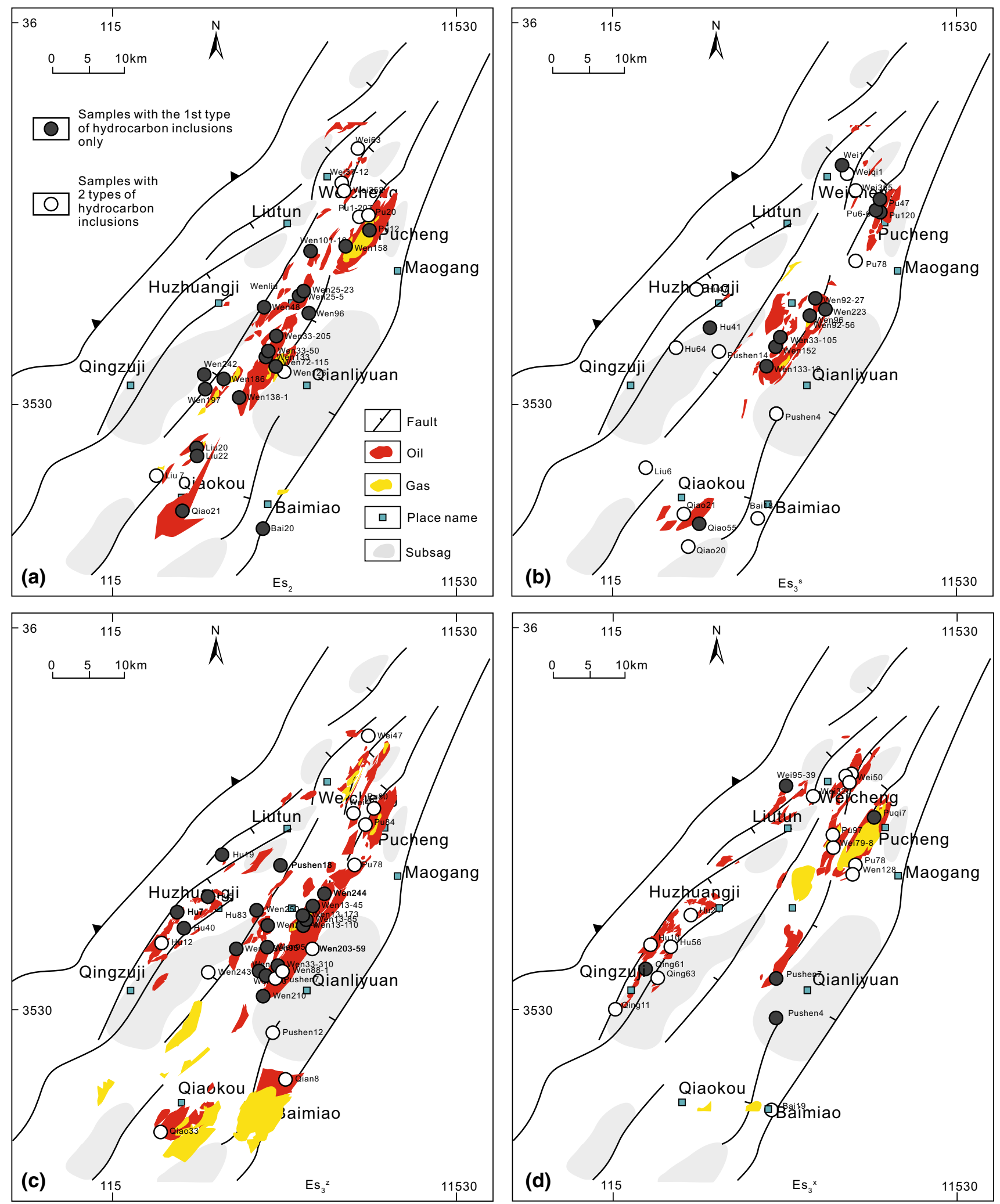

Fig. 9 Distribution of hydrocarbon inclusions in different stages in the major petroleum bearing formations of the northern Dongpu Depression, Bohai Bay Basin 
Table 3 Activity rate and time of the main source faults of the Dongpu Depression, Bohai Bay Basin

\begin{tabular}{|c|c|c|c|c|c|c|c|}
\hline \multirow[t]{2}{*}{ Fault name } & \multicolumn{6}{|c|}{ Fault active rate, $\mathrm{m} / \mathrm{Ma}$} & \multirow{2}{*}{$\begin{array}{l}\text { Fault active } \\
\text { time }\end{array}$} \\
\hline & $\mathrm{Ed}$ & $\mathrm{Es}_{1}$ & $\mathrm{Es}_{2}$ & $\mathrm{Es}_{3}^{\mathrm{s}}$ & $\mathrm{Es}_{3}^{\mathrm{z}}$ & $\mathrm{Es}_{3}^{\mathrm{x}}$ & \\
\hline Huanghe & 6 & 51 & 88 & 114 & 76 & - & $\mathrm{Es}_{3}^{\mathrm{z}}-\mathrm{Ed}$ \\
\hline Wendong 2 & 68 & - & - & - & - & - & $\mathrm{Ed}$ \\
\hline Wendong 3 & 21 & 53 & 13 & - & - & - & $\mathrm{Es}_{2}-\mathrm{Ed}$ \\
\hline Wenxi 1 & 19 & 56 & 139 & 237 & - & - & $\mathrm{Es}_{3}^{\mathrm{s}}-\mathrm{Ed}$ \\
\hline Wenxi 2 & 40 & 32 & 12 & - & - & - & $\mathrm{Es}_{2}-\mathrm{Ed}$ \\
\hline Xulou & 11 & 32 & 55 & 37 & - & - & $\mathrm{Es}_{3}^{\mathrm{s}}-\mathrm{Ed}$ \\
\hline Changyuan & 146 & 123 & 292 & 885 & 52 & 152 & $\mathrm{Es}_{3}^{\mathrm{x}}-\mathrm{Ed}$ \\
\hline Mazhai & - & - & - & - & 7 & 92 & $\mathrm{Es}_{3}^{\mathrm{x}}-\mathrm{Es}_{3}^{\mathrm{z}}$ \\
\hline
\end{tabular}

strong, so the oil and gas migrated to different layers and depths to accumulate. During the period of Dongying movement, an uplift occurred throughout the depression, the fault activity increased, and had great influence on the distribution and reorganization of oil and gas reservoirs, which resulted in a wide range of oil and gas distribution in the plane and vertical direction. In the second phase of hydrocarbon charging period, most of the faults were not active, and due to the plugging of salt rocks, oil and gas could not migrate along faults at a large-scale, so most accumulated near the sources. This results in the oil and gas formed in the second phase being mainly distributed in the vicinity of the sags in the horizontal plane and mainly concentrated in the main hydrocarbon generation layers vertically.

\section{Conclusions}

1. The main hydrocarbon source rocks of the Dongpu Depression mainly had two expulsion periods. The fluorescence microscopic features also indicated two stages of hydrocarbon accumulation. The carbonaceous asphalts, bituminous asphalts and colloidal asphalts reflect an early oil and gas injection phase, whereas the oleaginous asphalt reflects a second oil and gas injection phase.

2. According to the diagenetic evolution sequence, fluid inclusion petrography and the reservoir burial history analysis, hydrocarbon inclusions were divided into two formation phases. Phase I occurs in carbonate cements, internal cracks of quartz grains and dissolution pores of feldspars, corresponding to the early hydrocarbon filling. Phase II occurs in late cracks through quartz grains, corresponding to the late oil and gas filling.

3. Based on the comprehensive analysis of the hydrocarbon generation and expulsion histories of the major source rocks, fluorescence microscopic characteristics and reservoir fluid inclusions, the pool-forming in northern Dongpu Depression is found to be in two phases. The first phase was from the late Dongying depositional period to the early uplift period in the late Oligocene, while the second was from the late Minghuazhen period of the Pliocene to the Quaternary, with the first phase being the main hydrocarbon charge phase. The first phase of hydrocarbon reservoir charging was distributed across the whole region, whereas the second phase of the hydrocarbon reservoir accumulation was mainly distributed near the sub-sags and mainly in the hydrocarbon generation layers. In the vertical direction, it was characterized by a single phase in the upper layers and two phases in the lower layers within the Shahejie group.

Acknowledgements This work was supported by the Important National Science \& Technology Specific Projects (Grant No. 2011ZX05006-003/004).

Open Access This article is distributed under the terms of the Creative Commons Attribution 4.0 International License (http://crea tivecommons.org/licenses/by/4.0/), which permits unrestricted use, distribution, and reproduction in any medium, provided you give appropriate credit to the original author(s) and the source, provide a link to the Creative Commons license, and indicate if changes were made.

\section{References}

Chen SP, Qi JF, Wang DR, et al. Fault systems and transfer structures in Dongpu Sag. Acta Pet Sin. 2007;28(1):43-9.

Dolníček Z, Kropáč K, Janíčková K, et al. Diagenetic source of fluids causing the hydrothermal alteration of teschenites in the Silesian Unit, Outer Western Carpathians, Czech Republic: petroleumbearing vein mineralization from the Stříbrník site. Mar Pet Geol. 2012;37(1):27-40.

Gui Y, Liu K, Liu S, et al. Hydrocarbon charge history of Yingdong Oilfield, Western Qaidam Basin. Earth Sci J China Univ Geosci. 2015;40(5):890-9.

Guo LG, Tian H, Jin YB, et al. Reaction mechanism, medium influencing factors and identification and evaluation of oilcracking gas. Geochimica. 2008;37(5):499-511 (in Chinese).

Guo S, Tan LJ, Lin CY, et al. Hydrocarbon accumulation characteristics of beachbar sandstones in the southern slope of the Dongying Sag, Jiyang Depression, Bohai Bay Basin, China. Pet Sci. 2014;11(2):220-33.

Guo XW, Liu KY, He S, et al. Petroleum generation and charge history of the northern Dongying Depression, Bohai Bay Basin, China: insight from integrated fluid inclusion analysis and basin modelling. Mar Pet Geol. 2012;32(1):21-35.

Jarmołowicz-Szulc K, Łukasz K, Marynowski L. Fluid circulation and formation of minerals and bitumens in the sedimentary rocks of the Outer Carpathians-based on studies on the quartzcalcite-organic matter association. Mar Pet Geol. 2012;32(1):138-58.

Jiang FJ, Pang XQ, Yua S, et al. Charging history of Paleogene deep gas in the Qibei sag, Bohai Bay Basin, China. Mar Pet Geol. 2015a;2015(67):617-34. 
Jiang YL, Liu H, Song GQ, et al. Relationship between geological structures and hydrocarbon enrichment of different depressions in the Bohai Bay Basin. Acta Geol Sin. 2015b;89(6): 1998-2011.

Jiang YL, Liu P, Song GQ, et al. Late Cenozoic faulting activities and their influence upon hydrocarbon accumulations in the Neogene in Bohai Bay Basin. Oil Gas Geol. 2015c;2015(4):525-33 (in Chinese).

Lang DS, Jiang DH, Yue X, et al. Fluorescence microscopy, light hydrocarbon analysis technology and their application in oil exploration and development. Beijing: Petroleum Industry Press; 2008. p. 15-48 (in Chinese).

Li HT. Accumulation process and pattern of oolitic shoal gas pools in the platform: a case from member 3 of Lower Triassic Feixianguan Formation in the Heba area, northeastern Sichuan Basin. Pet Explor Dev. 2016;43(5):18-23.

Li N, Chen YJ, Deng XH, et al. Fluid inclusion geochemistry and ore genesis of the Longmendian Mo deposit in the East Qinling Orogen: implication for migmatitic-hydrothermal Mo-mineralization. Ore Geol Rev. 2014;63(1):520-31.

Lin ZM, Zhu XP, You F, et al. Nuclei fluorescence microscopic observation on early embryonic development of mitogynogenetic diploid induced by hydrostatic pressure treatment in olive flounder (Paralichthys olivaceus). Theriogenology. 2015;83(8):1310-20.

Liu DH, Lu HZ, Xiao XM. Fluid inclusions and their application in hydrocarbon exploration and development. Guangzhou: Guangdong Science and Technology Press; 2007. p. 29-44 (in Chinese).

Liu KY, Julien B, Zhang BS, Zhang N, et al. Hydrocarbon charge history of the Tazhong Ordovician reservoirs, Tarim Basin as revealed from an integrated fluid inclusion study. Pet Explor Dev. 2013;40(02):171-80.

Liu L, Ren ZL, Cui YB, et al. Distribution of present-day geothermal field in the Dongpu Sag. Chin J Geol. 2007;42(4):787-94 (in Chinese).

Liu Y, Zhong NN, Tian YJ, et al. The oldest oil accumulation in China: meso-proterozoic Xiamaling Formation bituminous sandstone reservoirs. Pet Explor Dev. 2011;38(4):503-12.

Lu XS, Jiang YL, Chang ZH, et al. Calculation of the erosion thickness of Dongying Formation in Dongpu Depression and its significance. Geol Sci Technol Inf. 2007;26(2):8-12 (in Chinese).

Luo XP, Cao J, Shen ZM. Geochemical characteristics and genesis of reservoir bitumen of Xujiahe Formation in the Upper Triassic of Western Sichuan Depression. J Mineral Pet. 2009;29(1):93-8 (in Chinese).

Lü ZX, Ye SJ, Yang X, et al. Quantification and timing of porosity evolution in tight sand gas reservoirs: an example from the Middle Jurassic Shaximiao Formation, western Sichuan, China. Pet Sci. 2015;12(2):207-17.

Makeen YM, Abdullah WH, Pearson MJ, et al. Thermal maturity history and petroleum generation modelling for the Lower Cretaceous Abu Gabra Formation in the Fula Sub-basin, Muglad Basin, Sudan. Mar Pet Geol. 2016;2016(75):310-24.
Muhammad T, Asifullah K. Protein subcellular localization of fluorescence microscopy images: employing new statistical and Texton based image features and SVM based ensemble classification. Inf Sci. 2016;2016(345):65-80.

Pang XQ, Jia CZ, Wang WY. Petroleum geology features and research developments of hydrocarbon accumulation in deep petroliferous basins. Pet Sci. 2015;12(1):1-53.

Parnell J. Potential of palaeofluid analysis for understanding oil charge history. Geofluids. 2010;10(1-2):73-82.

Qin KZ, Guo SH. Petroleum asphaltene. Beijing: Petroleum Industry Press. 2002; p. 2-16 (in Chinese).

Shalaby MR, Hakimi MH, Wan HA. Geochemical characterization of solid bitumen (migrabitumen) in the Jurassic sandstone reservoir of the Tut Field, Shushan Basin, northern Western Desert of Egypt. Int J Coal Geol. 2012;100(3):26-39.

Shan XQ, Zhang BM, Zhang J, et al. Paleofluid restoration and its application in studies of reservoir forming: a case study of the Ordovician in Tarim Basin, NW China. Pet Explor Dev. 2015;42(3):301-10.

Shokrlu YH, Babadagli T. In-situ upgrading of heavy oil/bitumen during steam injection by use of metal nanoparticles: a study on in situ catalysis and catalyst transportation. SPE Reserv Eval Eng. 2013;16(3):333-44.

Tao SZ. Sequence of diagenetic authigenic mineral: the basis of timing the inclusions formation in sedimentary rocks. Pet Explor Dev. 2006;33(2):154-60 (in Chinese).

Wang B, Feng Y, Zhao YQ, et al. Determination of hydrocarbon charging history by diagenetic sequence and fluid inclusions: a case study of the Kongquehe area in the Tarim Basin. Acta Geologica Sinica (English Edition). 2015a;89(3):876-86.

Wang TT, Yang SY, Duan SS, et al. Multi-stage primary and secondary hydrocarbon migration and accumulation in lacustrine Jurassic petroleum systems in the northern Qaidam Basin, NW China. Mar Pet Geol. 2015b;62:90-101.

Wu N, Cai ZX, Yang HJ, Wang ZQ, et al. Hydrocarbon charging of the Ordovician reservoirs in Tahe-Lunnan area, China. Sci China (Earth Sci). 2013;56(5):763-72.

Xiao H, Zhao JZ, Yang HJ, et al. Fluid inclusion and micro-FTIR evidence for hydrocarbon charging fluid evolution of the Ordovician reservoir of Halahatang Depression, the Tarim Basin. Earth Sci J China Univ Geosc. 2012;37:163-73.

Xiao ZY, Li MJ, Huang SY, et al. Source, oil charging history and filling pathways of the Ordovician carbonate reservoir in the Halahatang Oilfield, Tarim Basin, NW China. Mar Pet Geol. 2016;73:59-71.

Yang P, Xie Y, Wang ZJ, et al. Fluid activity and hydrocarbon accumulation period of Sinian Dengying Formation in northern Guizhou, South China. Pet Explor Dev. 2014;41(3):346-57.

Ying FX, Luo P, He D B. Diagenesis and diagenetic numerical simulation of clastic-rock reservoirs in petroleum basins of China. Beijing: Petroleum Industry Press. 2004; p. 47-86 (in Chinese).

Zhao XZ, Jin Q, Jin FM, et al. Origin and accumulation of highmaturity oil and gas in deep parts of the Baxian Depression, Bohai Bay Basin, China. Pet Sci. 2013;10(3):303-13. 